\title{
The Burden of Tuberculosis as a Permanent Medical and Legal Challenge for Mankind through Centuries
}

\author{
Milan Radović́1,2,3, Aleksandar Đorđević4 ${ }^{4}$ Borislav Božanić ${ }^{1}$ \\ ${ }^{1}$ Clinic for Pulmonary Diseases, University Clinical Center Niš, Niš, Serbia \\ ${ }^{2}$ Clinic for Thoracic Surgery, University Clinical Center Niš, Niš, Serbia \\ ${ }^{3}$ University of Niš, Faculty of Medicine, Department of Internal Medicine, Niš, Serbia \\ ${ }^{4}$ University of Niš, Faculty of Law, Chair of Legal History, Niš, Serbia
}

SUMMARY

Tuberculosis (TB) is a contagious disease, and throughout human history, it has been permanently opening numerous medical and legal questions, for which the answers are implied by the current social circumstances.

In ancient times, insufficient knowledge of the etiopathogenesis of TB resulted in discrimination and isolation of patients. In the Middle Ages, kings used TB as a disease to secure their political power over the citizens, while TB culturally took a romanticized form during the $19^{\text {th }}$ and $20^{\text {th }}$ centuries, together with a great social phobia of contagion, disease, and dying on the other hand. Stereotypes were formed around all TB victims, while society tried to understand the nature of the disease and establish a civilizational relationship with it as a health problem having numerous social implications. Modern public health measures for the control of the TB pandemic were established after the discovery of the Koch bacillus in the $19^{\text {th }}$ century. The invention and mass use of the BCG vaccine, the discovery of streptomycin and isoniazid, and the new era of TB treatment, with the consequent emergence of drug resistance, coepidemic with AIDS, neglect of public health facilities and the current COVID-19 pandemics threaten many legal rights of the infected and the sick and pose new challenges in its global elimination.

Numerous attempts by society over the centuries to devise preventive and therapeutic measures for TB, through different levels of social obligations and activities, have had and continue to have a profound impact on the human race, shaping its further response to the victims of this deadly disease.

Key words: tuberculosis, history, legal power, legal rights

Corresponding author:

Milan Radović

e-mail: milanradovic@ptt.rs 


\section{INTRODUCTION}

Tuberculosis (TB) is a communicable disease which occurs and develops by the infection with bacilli of Mycobacterium tuberculosis, the foremost common within the lung and the other organs of the human body, producing characteristic tubercular nodules in the affected organ as the commonest morphopathological substrate (1). As opposed to the foremost common communicable disease in the human history, tuberculosis has "cursed" the whole of mankind, from ancient times to this day, producing major epidemic cycles, making the Mycobacterium tuberculosis the most important reason behind the disease for the last 7 millennia, and currently liable for quite two billion infected people worldwide and approximately 10.4 million new cases with 1.4 million TB deaths annually $(2,3)$.

Owing to its infectious nature, the specific immune reaction of the infected organism, the chronically progressive course of the disease, and therefore the need for long-term treatment and recovery of patients, TB has always been a worldwide health burden (4). At the start of the $21^{\text {st }}$ century, the rapidly growing phenomenon of multi-drug resistant types of the disease, AIDS co-epidemic and ongoing COVID-19 pandemic, make TB actual again. This is a result of neglecting the public health agencies roles, the insufficient implementation of recommendations and techniques given by the World Health Organization and many UN Organizations, as well as the legal rights of infected and sick people. Therefore, despite a continuous socio-economic progress of the mankind, TB remains permanent medical and legal challenge throughout human history $(1,5,6)$.

\section{THE FIRST DESCRIPTIONS OF THE DISEASE AND LEGAL ASPECT OF SICK PEOPLE IN ANCIENT TIMES}

Due to the low mutation rate of mycobacteria, it is believed that the primary sort of this bacillus originated 150 million years ago (7). The primary archaeological findings on skeletons from the Neolithic period indicate the traces of the existence of TB. The first written documents about TB date back to the time of ancient Babylon (around 1900 BC), where the symptoms of the disease were described on tablets and relics. The Code of Hammurabi, Babylonian legal text of $1754 \mathrm{BC}$, describes a characteristic lung disease in such a way that it most indicates pulmo- nary TB (8). Tuberculosis is additionally mentioned within the Bible, Leviticus 26:16, where God warns the people of Israel, saying, "I will do that also to you: I will be able to send you fear, dry disease, and fever, which can corrupt your eyes and make your soul mourn." Sickness was considered a punishment from God, sent to those that committed sinful deeds $(8,9)$.

In precedent days, among the Europeans, the Greeks were the first in the development of medical practice, and describing TB or phthisis, as it was then known, set a precedent within the field of therapy and treatment. Greek doctor Aretaeus held that slender, thin, and paler people were more liable to disease than others. Hippocrates concluded that phthisis could be a disease, observing its mode of manifestation among members of the family, while the Greek physician Galen rejected this concept, and thought of it to be a communicable disease $(8,10)$. Galen believed that the cough of a sufferer pollutes the air and advised that people who coughed should be avoided, stating that their treatment should be done at high altitudes, where the air is fresher and cleaner, in contrast to the then medical principles of referring patients for the treatment into temples with warmer climate $(10,11)$.

With the growing awareness of $\mathrm{TB}$ as a contagion, there was social discrimination against patients and its integration into customary law. Hippocrates was warning Greek doctors to avoid treating severe cases of phthisis as death was inevitable in those patients because there was no effective cure and patient's death would significantly affect the doctor's reputation in terms of their inability to cure the patient (12). In this way, this sort of discrimination left some seriously ill people with no hope of surviving the disease. However, doctors failed to reject all patients. A number of them were sent to temples, or on an extended travel to the ocean to be healed. In this way, a specific variety of social isolation of the sick from the healthy population was created. There are two reasons for this sort of isolation. Some physicians and philosophers, like Galen, believed that the disease was transmitted by air and, therefore, separating the sick from the healthy prevented the spread of the disease. However, the majority of the Greek population believed that the sick man was punished by angry gods, which deepened the prevailing fear of the sick (13). On the other hand, in ancient times, the Greeks were in constant wars and had a large need for healthy 
soldiers, and sick men in this sense were considered useless and not deserving any respect (14). Also, the community considered any woman who fell ill useless, because the disease would make it impossible for her to try and do her regular household chores.

On the other hand, the Romans, as great admirers of the work of ancient Greece, did not consider the profession of a doctor to be the foremost socially profitable and infrequently left it to the Greeks. They had the standard legal rule that the household was to blame for preventing the disease so that the head of the household would adequately thank the gods, that the disease, even TB, would never "cross the threshold" of that household or hit any of its members (15). Byzantine physicians like Aetius of Amida, Alexander of Thrall, and Paul of Aegina described pulmonary and lymphoglandular types of TB, while within the Arab world, Avicenna hypothesized the contagious nature of pulmonary TB symptoms and described characteristic anatomical tuberculous lung lesions (1). The Romans, although they did not take steps to achieve new knowledge about the treatment of phthisis, were the first to introduce a system of specialized hospitals for the care of TB patients, which might eventually become a crucial aspect of treatment (10). With the fall of the Roman Empire and therefore the invasion of the Germanic tribes in 476, the population soon began to emigrate from cities to less populated and rural areas. Lack of travel and adequate social interaction has reduced the spread of TB infection (10, 15, 16). However, within the late Middle Ages, there have been intensive migrations of the rural population to the cities and thus TB again showed its dark side.

\section{THE DISCOVERY OF CHARACTERISTIC MORPHOPATHOLOGICAL TUBERCULOSIS LESIONS AND FIRST LEGAL REGULATIONS REGARDING THE TREATMENT OF PATIENTS IN MIDDLE AGE AND RENAISSANCE}

In medieval Europe, scrofula, or cervical $\mathrm{TB}$, became the foremost widespread type of this disease among the poor citizens, creating large tumor-like masses on the face and neck. In medieval France and England, especially among the Christians of that time, there was a belief that scrofula was a consequence of a sin committed which the divine touch of the king could cure (8). Since the majority of the population lived in severe poverty and thus had the best chance of contracting scrofula, this class of the population also received the foremost royal touches $(8,10)$. On the other hand, treatment was available to every class. It is believed that the "King's touch" originated from the time of the French king Robert the Pious in the $11^{\text {th }}$ century. The implementation of this act of non-medical treatment reached its peak in England within the 17th century, when the English King Charles II touched over 100,000 sick people (8). The thought of a divine royal touch of healing gained increasing popularity over time since in most cases scrofula was not a deadly form of TB, and after the "King's touch", the patient would usually enter the remission of the disease naturally, believing that the king had cured him (17). Contrarily, the disease was characterized by spontaneous relapses, even in seemingly cured patients, and that they would return to the king to be touched and cured again (10). Although the disease was often recurrent in humans, complete recovery immediately after contact with the king firmly assured them that the king had cured them (8).

The belief in the healing powers of the king had an enormous impact on the political system of the time. It may be said that they gave legitimacy to the king to remain on the throne. The king would tell his subjects that he was blessed by God he chose to be ruled by because he "treated" sick people in this way. We should always also keep in mind the fact that Christians in Medieval Europe were very fearful of God and his wrath because the literature of that time was describing God as ruthless and vengeful. The hierarchy was such that God was omnipotent and unlimited in "his will", while a person was subject to their will. Precisely for these reasons, "authority" was not important to the Christians of that time, because it was considered to be subordinated to God's will and rule, and not to kings. The rulers knew that the only way for the people to be loyal to them was to label themselves as someone sent in the name of God to rule. Although the right received from God was not a new idea, in the spiritual sense, it had great significance among the first Christians. If both the Roman Emperor and therefore the pagan king identified themselves as God's messengers, Christians would reject it, believing that the Christian God was not identical because of the God of rulers $(8,10)$. In this sense, the "King's touch" strengthened the idea that kings were chosen by God. Christians, fearing the wrath of God, submitted themselves to the king's will $(10,15)$. In this way, 
many medieval kings got the chance to usurp the throne and build their own dynasty (17). Their ability to "cure" their subjects from scrofula gave them legitimacy for an additional rule because their subjects were convinced that they were the king's messengers of God. By the beginning of the $18^{\text {th }}$ century, the idea of the healing properties of the King's touch was not widespread, and therefore the practice of the "King's touch" slowly began to die out as more intensive development of science and education began $(15,18)$. The last recorded "Royal touch" was in 1825, when King Charles X touched the last patient with TB (18).

The first definition of $\mathrm{TB}$, as a communicable disease, was given by Girolamo Fracastoro in the $16^{\text {th }}$ century (19). Shortly afterward, in Italian health legislation, in an edict issued by the Republic of Lucca in 1699, the primary official reference appeared regarding the contagious nature of this disease (20). For 175 years, the Health Board of the Republic ordered the mandatory notification and isolation of the infected, prohibiting their admission to public hospitals and forming special places for their treatments $(19,20)$.

\section{THE INFECTION THEORY, ISOLATION OF THE TUBERCULOSIS BACILLUS, LEGAL POWER AND LEGAL RIGHTS OF THE PATIENTS DURING THE INDUSTRIAL REVOLUTION}

Over the past few centuries, different beliefs have emerged about the nature of the disease. One of the beliefs that have become widely accepted in the medical community is its contagious nature. The term infection in that period was considered to mean that the disease could be transmitted in close contact between the sick and healthy people (8). The first written records about the addictive nature of $\mathrm{TB}$ were found in the work of Girolamo Fracastoro's entitled: "De morbis contagious", which was written in 1546, whose ideas and principles in medical practice were accepted in the $18^{\text {th }}$ century (10). Giovanni Battista Morgagni, was one of many $18^{\text {th }}$ century physicians who refused to perform autopsies of TB ill people out of fear of infection (8). Although the contagious nature of $\mathrm{TB}$ at that time had not yet been scientifically proven and explained, and the general belief about its contagious nature was constantly growing $(8,10)$.

In Western Europe, legal regulations related to $\mathrm{TB}$ patients served primarily as a legal means to fight diseases and prevent the spread of infection. In the $18^{\text {th }}$ century, Italian laws provided for the obligation to report a patient to the competent authorities, as well as the obligation to burn their personal belongings. If a doctor failed to report a sick patient, the first fine would be a fine of 300 ducats, and if the same case were repeated, the penalty would be an exile for ten years (10). The cruelty of the punishment shows the Italian government's fear of the potentially contagious nature of TB. On the other hand, Polish legal acts from the $14^{\text {th }}$ century expelled everyone suffering from TB from society, and their property was seized and destroyed by burning. By the $18^{\text {th }}$ century, Poland introduced a legal obligation to report a TB patient to the competent authorities, and then forced them into strict isolation in designated quarantine areas, with the burning of all his property (21). Although Western European and North American doctors, especially those from the United States, suspected that TB was contagious, the people still believed that the disease was hereditary $(18,21)$. This way of understanding TB was easier to understand among ordinary people, given the then low health education, and thanks to Hippocrates, such an attitude was already rooted thousands of years ago. For these reasons, during the $19^{\text {th }}$ century, TB was rarely viewed as a contagious disease, which further led to an idealistic notion of its contagious nature and clinical manifestations (20).

People from Western Europe have described beauty in clinical symptoms and signs of infection, such as paleness, thinness, shimmering eyes, and blush on the cheeks, believing that these were desirable characteristics of a modern person of that time, which is why the idea of beauty was formed in Western society, especially among women. This ideal was supported even more by the fact that most young girls of that time were more likely to suffer from TB than older ones (22). Not only were the symptoms of TB an association for bodily beauty but also an object of inspiration in works of art. TB sufferers often experienced bursts of optimism and euphoria known as spes phthisica, a term denoting the psychological state of denial of an existing condition in the sufferer, in terms of uncritical optimism, and which encouraged a certain higher degree of artistic creativity $(8,22,23)$.

While some provided a romanticized view of TB incidence, others had great fear. In the United States, in New England, 18\% of all TB deaths were reported by 1800 (23). In rural areas, people, due to 
larger families and close contacts with the nearest neighbours, after the death of a sick family member, or family members from the closest contact with the deceased would quickly develop symptoms of the disease and get sick. Friends and neighbours would accuse the deceased of being a vampire who sucked the life energy out of his family, and in this way, TB acquired a supernatural character $(23,24)$. On the other hand, in urban areas of the Western world, there were more rational fears, stemming from the perception of TB as a contagious disease. Thus, tuberculophobia began to occupy a significant place in the everyday life of the citizens at that time, since its contagious nature became generally accepted. This fear of getting sick and dying was abused in such a way that soon many inventions and patents in the field of medicine began to emerge from small, sometimes family research endeavours. These new drugs were considered to cure all diseases, although most of them were ineffective. Advertising agencies and companies stuck to these products, abusing the fear of $\mathrm{TB}$, to make as much profit as possible by selling them. Businesses began advertising products that were thought to not only prevent TB but also cure it. In this way, people hoped that it would save them from disease (8).

This fear also led to the adoption of new legislation to prevent the spread of TB in the population. Although milk was prescribed by Hippocrates for treatment, before the end of the $19^{\text {th }}$ and the beginning of the $20^{\text {th }}$ century, doctors advocated the introduction of mandatory pasteurization of milk in the United States, because it was known that bovine TB was transmitted to humans (25). At the beginning of the $20^{\text {th }}$ century, an average of up to $10 \%$ of TBinfected people was registered in the United States as a result of consuming infected cow's milk. These facts led to the proposal by the Food and Drug Administration (FDA) - the federal health agency to bind legal norms and procedures for pasteurization of milk, to permanently eliminate the bovine type of tuberculosis bacillus in the population (26). Although milk was not pasteurized at all at the beginning of the $20^{\text {th }}$ century, by 1936 , almost $98 \%$ of milk sold in the United States was pasteurized $(8,25,26)$.

Other laws of the time tried to specify antiepidemic modalities in the fight against TB. The Colorado State Legislature proposed a bill that anyone suffering from a contagious lung disease, most commonly tuberculosis should wear a belt around the neck to alert the environment about their disease (8). Almost all laws across the United States forbade spitting, which was common in people at that time, as a result of chewing tobacco, which led to spitting in many private homes, public places, and buildings (27). Concern for the public health of the nation soon transcended the existing cultural patterns of behaviour, and many cities prescribed internal legal norms to prevent and punish the habit of spitting $(8,10)$. The implementation of these laws varied from state to state, from city to city. In 1908, only $4 \%$ to $5 \%$ of "spitting" cases were reported in Indianapolis, compared to Minneapolis, where the law was strictly enforced so that in this state the habit of spitting in the city at all public places was completely abolished over time $(8,27)$. These laws were not adequately accepted in society, and many Americans felt they had the right to "spit" wherever they wanted, invoking the constitutionally guaranteed rights and freedoms of individuals. The counter-argument of this view was that it is the right of the state not to endanger the public health of the nation and that the rights of the majority outweighed the rights of the individual (28). This argument had greater legal and moral weight and the laws prohibiting spitting remained in force. The National Association for the Prevention of Tuberculosis (NAPT) of Great Britain, amazed by the success of anti-spitting legislation and policy in the United States, began to advocate and implement it wholeheartedly, which led some cities in Britain to adopt such policies and laws. In that sense, the spread of infection and TB was significantly prevented $(8,27,28)$.

Another consequence of tuberculophobia was the emergence of the "sanatorium movement" in the $19^{\text {th }}$ century when TB patients were often refused to be hospitalized, which was similar to the time of Hippocrates when doctors did not want to work with incurable patients because the disease itself limited their success in medical skills $(8,10)$. As society increasingly developed an increased awareness of the contagious nature of $\mathrm{TB}$, patients were being increasingly rejected for hospital treatment (29). Viewed through the eyes of the medical community, TB was an incurable disease, and admission of such a patient to hospital had no purpose in terms of space and resources which could be used more effectively on patients with other diseases, given the real danger of $\mathrm{TB}$ transmission in hospitals. For these reasons, sanatoriums for the treatment of TB patients were becoming an ideal solution for these patients. When the first sanatoriums were opened in 1859, the 
public condemned this type of hospital treatment and isolation, in terms of stigmatizing TB patients (30). After the general public began to raise awareness about the contagious nature of $\mathrm{TB}$, the construction of the sanatorium became massive in the United States and Western Europe. According to Dr. David Jacob Aaron Chowry-Muthu, a British sanatorium physician, an ideal sanatorium would be isolated at least 3 miles from a populated place or railroad (31). There, the treatment of patients consisted of continuous rest, inhalation of fresh air, and in some sanatoriums, doctors recommended mild physical training in the recovery phase of the patient (31). In sanatoriums, breathing fresh air was considered the key to recovery, so the basic TB therapy was to keep patients outdoors as often as possible where they could sit and/or lie on specially designed benches. This was one of the recognizable symbols of the first sanatoriums and very popular therapy method in many sanatoriums in the first decades of the $20^{\text {th }}$ century $(29-31)$.

The main goal of taking care of the TB patients in sanatoriums was to isolate them from the rest of the population. Some doctors, TB specialists, have even suggested mandatory isolation of patients (29). Thus TB patients in sanatoriums were isolated from the rest of the world. The location of the sanatorium was often outside the populated areas and railways, at higher altitudes, because the general public was frightened of the airborne contagious nature of $\mathrm{TB}$, believing that if they breathed the same air with the sick, the transmission of the disease was inevitable and therefore getting the disease was certain. On the other hand, the geographical isolation of the sanatorium made it difficult to go to visit these patients, and the social interaction of patients in these facilities with the outside world was very limited (30). In this way, the control of the infection transmission was implemented, but even without these prohibitions, most patients were already socially stigmatized publically and were considered exiles, rejected by the remainder of society $(30,31)$.

The population from the so-called "outside world" was very aware that some former sanatorium patients were not completely cured so that they were still considered contagious. For these reasons, they found it difficult to get employed after recovering and leaving the sanatorium, not only due to employers' fear of TB but also owing to the established belief that TB convalescents were less efficient as workers than they were before catching the disease (31).
There were two, frequently discussed options at the time, with the aim of resolving this problem. One option for former patients after discharge was to employ them there, because sanatoriums had numerous problems in terms of finding the workforce, owing to the existence of $\mathrm{TB}$ infection and stigmatization of sanatoriums by society (30 - 32). In this way, former patients not only got employment but also acquired social rehabilitation before returning to society (32). In this regard, it was proven that it is possible to re-incorporate former patients into society. On the other hand, after an extended period spent in a sanatorium, some patients developed an addiction thereto. A study conducted on patients at the Jefferson TB Sanatorium in 1948 found that a lot of patients feared losing their social position when returning to society because of a prior illness (33). Another choice for TB patient to avoid the rejection of the employer was to keep the fact of their previous hospitalization a secret. Some patients also concealed their previous illness from their families and relatives $(8,10,31-33)$. The social stigma that accompanied TB sufferers and cures was so strong that in some cases many former patients lost support and/or were rejected by their family members (33). Staying in sanatorium was a chance for a prior TB patient to become healthier and less contagious after getting back from sanatorium to the community, so TB gradually became a disease of public health importance. After Koch discovered TB in 1882 and made the greatest discovery of that time, a new historical epoch in TB care began, within which public health problems and also the creation of domestic and international legislation took precedence in looking for better solutions in response to the $\mathrm{TB}$ pandemic $(10,11)$.

\section{MODERN MEDICAL AND LEGAL ENVIRONMENT OF GLOBAL TUBERCULOSIS BURDEN}

In the early $20^{\text {th }}$ century, $\mathrm{TB}$ mortality in the United States ranged from 16\%-22\%, depending on the degree of "social welfare" of the population (8). Although the belief that TB was hereditary had ended, a new theory about the hereditary predispositions to the disease began to emerge. Migrants and national minorities, unlike the rest of the population, mostly lived in poverty, so they were more susceptible to TB. The famous American zoologist, Charles B. Davenport, opened the Eugenics 
Record Office in 1910 as part of the Station of Experimental Evolution on Long Island, which was dedicated to promoting the idea, superiority of the white race and the hereditary origin of TB (32). He believed that people with TB and other infectious diseases should not get married and have a family, because they would have disabled children, which would be a great burden for the state in terms of social benefits (33). The political activism of eugenists as an interest group of citizens implied activism in preventing marriages between sick people and they tried with their proposals to pass a law in the Congress on the prevention of such marriages $(8,32)$. The majority of citizens were convinced that the predispositions for contracting TB were hereditary, so the eugenicists presented a plan for sterilization of the patients on the wave of such an opinion, which the state authorities took into consideration (33). According to them, the sterilization plan would be easy to implement, because most TB patients were treated and stayed in sanatoriums $(8,33)$. However, as there was already too much evidence of the contagious nature of TB by 1930, eugenicists lost support in the population over time (33). Over time, the majority of the population realized that patients who were discharged from sanatorium were no longer contagious and that their stay and treatment in sanatoriums enabled a safe and secure return to society $(8,34)$.

During this period, as champions of the first effective attempt to overcome the challenges of TB as public health threat stand out Albert Calmette and Camille Guerin who invented the vaccine against TB in the newly created Pasteur Institute and Lille, France, where Calmette, the founder, and the first manager, tried to attenuate Mycobacterium bovis to make vaccine and succeeded in that $(35,36)$. After surviving World War I, Calmette found himself in Paris and 1921 tested the first BCG (Bacille Calmette Guerin) vaccine on a newborn from a mother with pulmonary $\mathrm{TB}$, which was also given to a grandmother who had $\mathrm{TB}$, too. The baby was the first subject to survive the infection and did not develop an active disease (37). In the next 7 years, over 100,000 children were immunized with the BCG vaccine in France, acquired immunity to $T B$, and vaccination became generally accepted in most European countries.

Mass immunization with BCG vaccine in the first half of the $20^{\text {th }}$ century led to a rapid decline in the number of TB patients, but the great devastation in the First World War rekindled the epidemic despite mass radiographic screenings of recruits in both Germany and the Allied armies. After the end of the war, a thirty-year radiographic screening of the civilian population followed, but it did not achieve significant results in terms of active disease prevention, which is why in England in 1945 lung radiography as a method of early detection of the disease was abandoned and the method of searching for individual contacts was forced (38). In 1948, UNICEF and the Danish Red Cross conducted an extraordinary global campaign to control $\mathrm{TB}$, based on tuberculin testing, with the consequent BCG vaccination of non-reactors. After 3 years, almost 30 million people were tested for tuberculin and almost 14 million people were vaccinated with BCG, which was the first infection control program implemented by the WHO (39). Finally, in 1974, the WHO Expert Committee on Tuberculosis issued its ninth annual TB report, a document that established global guidelines for TB control over the next two decades. This document rejected mass radiography and tuberculin testing of the population as a successful diagnostic tool and gave priority to sputum microscopy of symptomatic people and those at risk for the disease, which "pushed" immunization with BCG vaccine to cover $70 \%-90 \%$ of people aged 15 to 20 years (40). Today, the WHO continues to programmatically control TB globally, but BCG vaccination is no longer recommended for the whole population, except for newborns (36). In the United States, where BCG vaccination has not been widely used, the modern TB control program does not potentiate the prevention of the disease but gives priority to the treatment of latently infected individuals (35).

Three decades later, the perspective of tuberculosis patients and the history of TB are changing dramatically with the introduction of effective chemotherapy. The discovery of para-aminosalicylic acid (PAS) in 1943, and thiosemicarbazone during the war in Germany in 1945 created the first effective therapeutic agents (41). Albert Schatz, Elizabeth Bugie, and Selman Waksman discovered streptomycin in 1944, i.e. the first bactericidal antibiotic effective against Mycobacterium tuberculosis (42). In the next few months, this drug will achieve dramatically effective results in terms of therapy, especially for younger girls with TB (35). This success was followed by the discovery of Isoniazid, the first oral antituberculosis drug in 1952, followed by rifampicin in 1957 (43). A new era in TB treatment was coming, which is why most sanatoriums were closing. Public 
health measures also enabled adequate therapy for those patients with latent tuberculosis infection, thus initiating a new phase in the history of global TB control. The main goal in the second half of the $20^{\text {th }}$ century became the adequate treatment of the infected and the sick, which led to a significant drop in the mortality rate, but also decreased further funding for research and development of new drugs and vaccines between 1970 and 1990 (43). With the growing AIDS pandemic and the emergence of increasing secondary resistance to antituberculosis drugs, TB is re-emerging as a global threat to the public health of the population (44). While most of the existing diagnostic and therapeutic tools needed to combat the disease itself were largely outdated, new strategies for controlling and preventing infection emerged, including the 1993 DOTS strategy together with the 1998 DOTS PLUS program to address multidrug resistance to standard antituberculosis drugs of the 1st treatment line (multi-drug resistant TB-MDR-TB) (43). The regular WHO annual report on TB from 2009 states that despite all previous measures of prevention, early detection, and effective treatment, TB is still a significant public health problem with an average global annual mortality rate of 150,000 , and with about 480,000 new cases of MDR-TB, while in 2013 the most such cases were detected in India, China, and Russia $(43,45)$. In recent years, extensive drug resistance $(\mathrm{XDR})$ or MDR Plus drug resistance of the second line has become a new global problem, ending with $9 \%$ of newly discovered XDR-TB cases in 2013 (43).

Thanks to the efforts made in modern TB diagnosis and therapy, about 37 million lives were saved between 2000 and 2013 (46). However, maintaining this success was difficult to sustain, due to the growing HIV co-epidemic, MDR and XDR forms of TB, BCG vaccine ineffectiveness, and the growing false positive results of the existing TB tests, but also non-compliance with prescribed treatment regimens and delays in developing new therapeutic modalities. The WHO has presented a new global TB control framework called "the STOP TB strategy", which insists on the implementation of the six identified main objectives, which should be implemented in all member states in order to reduce a TB infection and disease, both locally and nationally. The basic way to achieve this at the global level consists of improving and upgrading the existing TB therapy, better access to health care for as many people as possible and investment in new research (46). The whole world began to hope that at least some of the proclaimed goals will be achieved soon.

The desire of the entire scientific and professional community to challenge the gloomy statistical forecasts as soon as possible led to the establishment of a broad global consensus in 2015 to rapidly prevent the spread of this deadly infectious disease. In September 2015, UN members unanimously adopted the Sustainable Development Agenda, which set ambitious goals for eliminating TB and HIV as global threats to public health by 2030 (47). However, between 2000 and 2014, the incidence of TB fell by only $1.5 \%$ per year, and with such annual progress, global targets would not be achieved until 2182, necessitating a decisive and precise change in the existing program solutions (48). A priority of key changes in program policy in the new millennium are new achievements in improving the diagnosis and treatment of $\mathrm{TB}$, along with reducing the cost of treatment. On the other hand, at the level of various WHO member states, there are policy changes in implementing goals, primarily the wider availability of modern tools to combat TB, which has become the key to solving the problem of the pandemic. Given that TB mostly "attacks" those who are more socially vulnerable, or marginalized such as people with HIV, those who use narcotics, migrants, the urban and rural poor, minors and children, prisoners, women, and single mothers, the states are facing with important social challenges in achieving more efficient care for those infected and suffering from TB. These and similar challenges are further jeopardized by policies and practices of the constant collapse of human rights and freedoms, especially in the field of gender equality, denying certain segments of the population access to effective and necessary medicines, generating a lack of courage to seek and provide adequate medical care. In most WHO member states, the legislation provides for a high degree of protection of many human rights and freedoms, but in practice, their implementation is low (49).

As a result of these shortcomings in legal practice, people with TB suffer both from the infection itself and the impact that infection has on having other human rights. People with TB can fall into serious poverty due to job loss as well as high therapy costs. They can also be forcibly hospitalized, isolated, and/or preventively locked up (50). Stigmatization and discrimination related to $\mathrm{TB}$ are also accompanied by discrimination based on HIV status, 
gender, wealth, or in some other way. Such differences lead to the establishment of new barriers in terms of access to adequate care and therapy for each affected individual. The STOP TB Partnership and the WHO presented a set of Millennium Development Goals to end the TB pandemic (50). WHO's post-2015 End TB Strategy insists that member states must recognize the existence of these ethical dilemmas and numerous inequalities within their populations, especially in terms of social aspects and support of all forms of national dialogues to address these societal problems $(48,50)$. For these reasons, a joint strategy has been created based on improving the prescription of adequate therapy by physicians, establishing instruments for the implementation of the prevention strategies, on the one hand, and providing enforcement mechanisms in case of failure of previous measures, on the other, to legal power and state legislation establishment, maintenance of public confidence, creating thus the basis for further comprehensive and economically viable $\mathrm{TB}$ control programs (50).

MEDICAL AND LEGAL CONSIDERATIONS FOR FURTHER IMPLEMENTATION OF GLOBAL STRATEGIES FOR TUBERCULOSIS CONTROL DURING THE COVID-19 PANDEMIC

As the modern world is uniting today in terms of resolving the COVID-19 pandemic, it is important to ensure the resolution of other pre-existing health and legal aspects of other infectious diseases, to protect people's health and life, but also to solve numerous problems in the public domain. Health care, including national legislative measures in the fight against $\mathrm{TB}$, must be more efficient and faster about the current course and response to the COVID-19 pandemic and should enable a sustainable state of all aspects of the state apparatus and health system, in terms of providing services related to the infected and TB patients (51).

Current modelling of previous work with TB patients due to the COVID-19 pandemic has already lead to a global reduction in the detection of TB patients by $25 \%$. In only three months since the beginning of the pandemic, with a projected increase in TB mortality rate of $13 \%$, the TB mortality rate was the same as it was 5 years ago (52). This gloomy prediction does not take into account other contributing factors related to the transmission of TB bacillus in- fection, discontinuity in the care and treatment of patients, as well as poorer prognosis and outcome in TB patients with associated SARS-CoV-2 infection (52). For these reasons, 1.4 million more deaths from TB are expected between 2020 and 2025, precisely as a direct consequence of the COVID-19 pandemic (53). WHO advises member states, which lead the current software solutions in the COVID-19 pandemic through the WHO Global TB program, to develop certain adaptation mechanisms for maintaining the existing measures in TB control through modern information technologies. WHO also affirms necessary professional and financial assistance to national TB programs in order to provide the necessary emergency medical and legal services in working with TB patients affected by the COVID-19 pandemic, resulting in supported treatment of both diseases $(54,55)$. The successes achieved so far in the fight against TB must not be annulled by the COVID-19 pandemic. Detection and treatment of TB patients remain the primary goal of programmatical addressing the TB pandemic, which still requires continuous monitoring (51 - 55).

The COVID-19 pandemic further emphasizes the existing stigmatization of the weak and sick, as well as discriminatory behaviours against certain vulnerable groups, including those from contact with the SARS-CoV-2 virus (54). Stigma can undermine social interaction and connection and create an insurmountable social wall against such population groups. The circumstances in which the TB virus and bacillus spread together also contributed to this condition (54 - 56). Enabling trust in reliable medical recommendations and services, showing empathy for those affected by the disease, and understanding the nature of the disease itself is an important and effective legal and socially useful measure to protect people as well as the health of their loved ones (54). Governments, citizens, the media, and communities have an important role to play in preventing the stigmatization of patients (54 - 56). The provision of all available and recommended health and legal services to TB patients during the COVID-19 pandemic must not be discontinued (56). As the "dark cloud" of the pandemic is clearing up, the collection of new evidence will be crucial in shaping the new legal and medical norms to support modern principles of conscientious treatment and respect for the privacy of patients during certain sensitive clinical endeavours. 


\section{CONCLUSION}

The infected were often isolated in sanatoriums, which formed numerous stereotypes about the sick and the disease itself. Over the time, there has been a marked lack of understanding of TB as a contagious disease or a pandemic itself. People did not know what the cause of it was, how it was spreading, and who was at risk of getting the disease. On the other hand, society has formed its often imprecise, illogical, and scientifically unfounded explanations for numerous social consequences of TB. Many patients experienced serious stigma and social discrimination due to the infection and were therefore forced into certain forms of social isolation. Governments have enacted various laws and legislative measures to control the TB epidemic, which in socio-economic terms has affected a large number of citizens. The lack of understanding of the TB pandemic has, in certain situations, caused uncontrolled mass hysteria among people in the Western world. In addition to the fact that the TB bacillus affected a larger part of the population, it had the greater impact on the state, which tried to implement measures to prevent and treat the disease by introducing and implementing various social obligations, responsibilities, and activities, all in the constant fight against TB. Evidence-based scientific explanations have had a key impact on the whole of the human society, and over time, continuous work on the health education of society has formed a modern attitude towards TB, as well as an adequate way for the treatment of patients in all the aspects, including the consequences that a deadly disease carried.

\section{Acknowledgments}

The authors of the article would like to express the deep and sincere gratitude to our research supervisor, Prof. Dr. Dragan Nikolić, PhD, former Head of Chair of Legal History, Faculty of Law, University of Niš, Serbia (retired in October 2020) and a member of the Council of the Center for Byzantine-Slavic Studies at University of Niš, Serbia, for providing invaluable guidance throughout this research. His dynamism, vision, sincerity, and motivation were deeply inspiring. It was a great privilege and honour to work and study under his guidance.

\section{Authors' contribution}

MR composed and supervised the manuscript. BB performed a search of the literature and contributed to the draft of the article. AĐ revised the manuscript critically. All authors read and approved the final version of the manuscript.

\section{Disclosure}

The authors report no conflicts of interest in this work. 


\section{References}

1. Barberis I, Bragazzi NL, Galluzzo L, et al. The History Of Tuberculosis: From The First Historical Records To The Isolation Of Koch's Bacillus. J Prev Med Hyg 2017; 58: 9-12. https://doi.org/ 10.1007/55842017125

2. Mac Donald EM, Izzo AA. Tuberculosis Vaccine Development - Its History and Future Directions. In: Ribbon W (Ed). Tuberculosis - Expanding Knowledge. IntechOpen, 2015. p. 1287-313. https://doi.org/10.5772/59658

3. World Health Organisation. Global Tuberculosis Report 2018. World Health Organization: Geneva, 2018: 1-7.

http://apps.who.int/iris/bitstream/handle/10665/27 4453/9789241565646-eng.pdf?ua $=1$

[Accessed on 27/12/2020].

4. Parmet WE. Legal Power And Legal Rights - Isolation And Quarantine In The Case Of Drug-Resistant Tuberculosis. N Engl J Med 2007; 357(5): 433-5. https://doi.org/10.1056/NEJMp078133

5. Gittler J. Controlling Resurgent Tuberculosis: Public Health Agencies, Public Policy, and Law. J Health Polit Policy Law 1994; 19(1): 107-47. https://doi.org/10.1215/03616878-19-1-107

6. Luca S, Mihaescu T. History of BCG Vaccine. Maedica (Buchar) 2013; 8(1): 53-8. PMID: 24023600.

7. Hayman J. Mycobacterium Ulcerans: An Infection From Jurassic Time? Lancet 1984; 2(8410): 1015-6. https://doi.org/10.1016/S0140-6736(84)91110-3

8. Lauer SA. The Social Impact of the Misconceptions Surrounding Tuberculosis. Iowa Historical Rev 2017; 7(1): 55-78. https://doi.org/10.17077/2373-1842-1039

9. Daniel VS, Daniel TM. Old Testament Biblical References to Tuberculosis. Clin Infect Dis 1999; 29(6): 1557-8.

https://doi.org/10.1086/313562
10. Waksman SA. The Conquest of Tuberculosis. University of California Press, Berkeley, USA, 1964: 29-64.

https://doi.org/10.1525/9780520328471

11. Pezzella, AT. History of Pulmonary Tuberculosis. Thorac Surg Clinics 2019: 1-17. https://doi.org/10.1016/j.thorsurg.2018.09.002

12. Pormann T, Peter E, Karimullah KI. The Arabic Commentaries On The Hippocratic Aphorisms: Introduction. Oriens 2017; 45: 1-52. https://doi.org/10.1163/18778372-04501006

13. Longrigg J. Death And Epidemic Disease In Classical Athens. Death And Disease In The Ancient City. Routledge 2002: 67-76. http://hdl.handle.net/10822/994206 https://doi.org/10.4324/9780203452950-13

14. Cushing A. Illness and health in the Ancient World. Collegian 1998; 5(3) : 44-6. https://doi.org/10.1016/S1322-7696(08)60304-2

15. Andrew W. J. N. Hays. The Burdens of Disease: Epidemics and Human Response in Western History. New Brunswick, N.J.: Rutgers University Press. 1998. Pp. xi, 361. Cloth 50.00, paper 24.00. Am Hist Rev 2000; 105(5): 1700-1.

https://doi.org/10.1086/ahr/105.5.1700

16. Santacroce L, Bottalico L, Charitos I A. Greek Medicine Practice At Ancient Rome: The Physician Molecularist Asclepiades. Medicines 2017; 4(4): 92-3. https://doi.org/10.3390/medicines4040092

17. Bray FN, Alsaidan M, Simmons BJ et al. Scrofula And The Divine Right Of Royalty: The King's Touch. JAMA Dermatol 2015;151(7): 702-6. https://doi.org/10.1001/jamadermatol.2015.0449

18. Brăilean T, Aurelian-Petrus P. Christianity And Political Democracy In The Middle Ages And Modern Times. Hum Soc Stud 2013; 2(2): 119-37. https://doi.org/10.2478/hssr-2013-0007 
19. Sabbatini S. Historical insights into tuberculosis. Girolamo Fracastoro's intuition on the transmission of tuberculosis and his opponents. History of an idea. Infez Med 2004; 12(4): 284-91. Italian. PMID: 15729021.

20. Barberis I, Bragazzi NL, Galluzzo L, et al. The history of tuberculosis: from the first historical records to the isolation of Koch's bacillus. J Prev Med Hyg 2017; 58(1): E9-E12. PMID: 28515626.

21. The White Plague Continues. Chapter 6. In: Roberts CA, Buikstra JE (Eds). The Bioarchaeology Of Tuberculosis: A Global View On A Re-Emerging Disease. Gainesville, FI: University Press of Florida, 2003. p 262-72.

https://dro.dur.ac.uk/3887/1/3887.pdf

[Accessed on 27/12/2020].

22. Morens DM. At The Deathbed Of Consumptive Art. Emerg Infect Dis 2002; 8(11): 1353-4. https://dx.doi.org/10.3201\%2Feid0811.020549

23. Bell ME. Vampires and Death in New England, 1784 to 1892. Anthropol Humanism 2006; 31(2): 124-40. https://doi.org/10.1525/ahu.2006.31.2.124

24. Sledzik PS, Bellantoni N. Bioarcheological And Biocultural Evidence For The New England Vampire Folk Belief. Am J Phys Anthropol 1994; 94(2): 269-74.

https://doi.org/10.1002/ajpa.1330940210

25. Hancox M. Bovine Tuberculosis: Milk And Meat Safety. The Lancet 2002; 359 (9307): 706-7. https://doi.org/10.1016/S0140-6736(02)07786-3

26. Olmstead AL, Rhode PW. An impossible undertaking: the eradication of bovine tuberculosis in the United States. J Econ His 2004; 64(3): 734-72. https://doi.org/10.1017/S0022050704002955

27. Abrams JE. Spitting Is Dangerous, Indecent, And Against The Law! Legislating Health Behavior During The American Tuberculosis Crusade. J Hist Med Allied Sci 2013; 68(3): 416-50. https://doi.org/10.1093/jhmas/jrr073

28. Coomber R, Moyle L, Pavlidis A. Public Spitting in "Developing" Nations of the Global South: Harmless Embedded Practice or Disgusting,
Harmful and Deviant? In: Carrington K, Hogg R, Scott J, Sozzo M (eds). The Palgrave Handbook of Criminology and the Global South. Palgrave Macmillan, Cham, 2018: p. 493-520.

https://doi.org/10.1007/978-3-319-65021-0 25

29. Muthu DJAC. Pulmonary Tuberculosis: Its Etiology and Treatment, a Record of 22 Years' Observation and Work in Open-air Sanatoria. William Wood \& Company, 1922:227-290.

https:/dspace.gipe.ac.in/xmlui/bitstream/handle/1 0973/34029/GIPE007194.pdf?sequence=3\&isAllow $\underline{\mathrm{ed}=\mathrm{y}}$

[Accessed on 27/12/2020].

30. Muthu DJAC. The Sanatorium Treatment of Pulmonary Tuberculosis-Is It a Success? Bristol Med Chir J (1883) 1907; 25(95): 50-4. PMID: 28896882.

31. Fairchild, AL, Oppenheimer GM. Public Health Nihilism Vs Pragmatism: History, Politics, And The Control Of Tuberculosis. Am J Public Health 1998; 88(7): 1105-17 https://doi.org/10.2105/ajph.88.7.1105

32. Young M. A Study Of The Adjustment Of Patients Discharged From The Jefferson Tuberculosis Sanatorium Between November 1945, And November 1946. ETD Collection for AUC Robert W. Woodruff Library 1948; Paper 428: 1-37. https://radar.auctr.edu/islandora/object/cau.td\%3A 1948 young mildred/datastream/OBJ/download [Accessed on 27/12/2020].

33. Wilson P K. Confronting "Hereditary" Disease: Eugenic Attempts To Eliminate Tuberculosis In Progressive Era America. J Med Humanit 2006; 27(1): 19-20.

https://doi.org/10.1007/s10912-005-9001-6

34. Caverhill TFS, Calwell Q, Guillemard BJ, et al. A Discussion On The Open-Air Or Hygienic Treatment Of Consumption. Br Med J 1898; 2 (1970): 946-9. PMCID: PMC2434310

35. Daniel TM. The history of tuberculosis. Respir Med 2006; 100(11): 1862-70.

https://doi.org/10.1016/j.rmed.2006.08.006

36. Daniel TM. Leon Charles Albert Calmette and BCG vaccine. Int J Tuberc Lung Dis 2005; 9: 205-6. 
PMID: 16158885

37. Calmette A. On preventive vaccination of the new-born against tuberculosis by B.C.G. Br J Tuberc 1928; 22: 161-5. https://doi.org/10.1016/S0366-0850(28)80052-4

38. Davies TW, Davies M. Mass radiography in Wales. Experience with a mobile unit. Br J Tuberc Dis Chest 1945; 391: 2-37. https://doi.org/10.1016/S0366-0869(45)80004-7

39. Comstock GW. The international tuberculosis campaign: a pioneering venture in mass vaccination and research. Clin Infect Dis 1994; 19: 528-40. https://doi.org/10.1093/clinids/19.3.528

40. Marx FM, Skachkova E I, Son IMet al. Die Kontrolle der Tuberkulose in den Nachfolgestaaten der Sowjetunion am Beispiel Russlands. Pneumologie 2009; 63(05): 253-60. https://doi.org/10.1055/s-0028-1119571

41. Schatz A, Bugie E, Waksman SA. Streptomycin, a substance exhibiting antibiotic activity against Gram-positive and Gram-negative bacteria. Proc Exp Biol Med 1944; 55: 66-9. https://doi.org/10.3181\%2F00379727-55-14461

42. Weitzman D, de Wend Cayley FE, Wingfield AL. Streptomycin in the treatment of pulmonary tuberculosis. Brit J Tuberc Dis Chest 1950; 44: 98-104. https://doi.org/10.1016/s0366-0869(50)80004-7

43. Fogel N. Tuberculosis: a disease without boundaries. Tuberculosis 2015; 95(5): 527-31. https://doi.org/10.1016/j.tube.2015.05.017

44. Keshavjee S, Farmer P. Tuberculosis, drug, resistance, and the history of modern medicine. $\mathrm{N}$ Engl J Med 2012; 367(10): 931-6. https://doi.org/10.1056/NEJMra1205429

45. Comas I, Gagneux S. The past and future of tuberculosis research. PLoS Pathog 2009; 5(10): e1000600.

https://doi.org/10.1371/journal.ppat.1000600

46. World Health Organization. Global tuberculosis report 2014. World Health Organization, 2014 https://apps.who.int/iris/handle/10665/137094
[Accessed on 27/12/2020].

47. STOP TB Partnership. Legal environment assessments for tuberculosis: an operational guide. Geneva, Switzerland: Stop TB Partnership, 2017. http://www.stoptb.org/assets/documents/communit ies/StopTB TB\%20LEA\%20DRAFT FINAL Sept $\% 2$ 027.pdf

[Accessed on 27/12/2020].

48. Global tuberculosis report 2016. Geneva: World Health Organization, 2016.

http://apps.who.int/iris/bitstream/10665/250441/1/ 9789241565394-eng.pdf?ua $=1$

[Accessed on 27/12/2020].

49. Out of step 2015: TB policies in 24 countries. 2nd Ed. Geneva: Médecins Sans Frontières and Stop TB Partnership; 2015.

https://msfaccess.org/out-step-tb-policies-24countries-2nd-ed-2015

[Accessed on 27/12/2020].

50. World Health Organization. The end TB strategy. World Health Organization, 2015.

https://apps.who.int/iris/bitstream/handle/10665/3 31326/WHO-HTM-TB-2015.19-eng.pdf

[Accessed on 27/12/2020].

51. Saunders MJ, Evans CA. COVID-19, tuberculosis, and poverty: preventing a perfect storm. Eur Respir J 2020; 56: 2001348. https://doi.org/10.1183/13993003.01348-2020

52. Glaziou P. Predicted impact of the COVID-19 pandemic on global tuberculosis deaths in 2020. Epidemiology 2020 May 4.

https://doi.org/10.1101/2020.04.28.20079582

53. WHO. Coronavirus disease (COVID-19) outbreak. 2020. https://www.who.int/emergencies/diseases/novelcoronavirus-2019

[Accessed on 27/12/2020].

54. IFRC, UNICEF, WHO. Social Stigma associated with COVID-19. A guide to preventing and addressing social stigma. 2020.

https://www.who.int/docs/defaultsource/coronaviruse/covid19-stigma-guide.pdf [Accessed on 27/12/2020]. 
55. WHO Guidelines on tuberculosis infection prevention and control, 2019 update (WHO/CDS/TB/2019.1). Geneva: World Health Organization. 2019.

https://apps.who.int/iris/bitstream/handle/10665/3 11259/9789241550512-eng.pdf

[Accessed on 27/12/2020].
56. WHO. Coronavirus disease (COVID-19) technical guidance: Infection prevention and control. WASH. https://www.who.int/emergencies/diseases/novelcoronavirus-2019/technical-guidance/infectionprevention-and-control [Accessed on 27/12/2020]. 


\title{
Breme tuberkuloze kao stalni medicinski i pravni izazov čovečanstva kroz vekove
}

\author{
Milan Radović́, ${ }^{2,3}$, Aleksandar Đorđević, Borislav Božanić ${ }^{1}$ \\ ${ }^{1}$ Univerzitetski Klinički centar Niš, Klinika za plućne bolesti, Niš, Srbija \\ ${ }^{2}$ Univerzitetski Klinički centar Niš, Klinika za grudnu hirurgiju, Niš, Srbija \\ ${ }^{3}$ Univerzitet $u$ Nišu, Medicinski fakultet, Katedra za internu medicinu, Niš, Srbija \\ ${ }^{4}$ Univerzitet $u$ Nišu, Pravni fakultet, Katedra za pravnoistorijske nauke, Niš, Srbija
}

S A ŽET A K

Tuberkuloza (TB) je kao zarazna bolest, tokom ljudske istorije, bila i ostala permanentni medicinski i pravni izazov, uz stalno prisutna otvorena pitanja, za koja su odgovori implicirani aktuelnim društvenim okolnostima.

U antičko doba, nedovoljno poznavanje etiopatogeneze TB imalo je za rezultat diskriminaciju i izolaciju obolelih. U srednjem veku, kraljevi su koristili oboljevanje od TB da bi osigurali političku vlast nad svojim podanicima, a tokom 19. i 20 . veka, TB je u kulturološkom smislu poprimila romantizovanu formu, dok je sa druge strane postojala velika društvena fobija od zaraze, oboljevanja i umiranja. Stereotipi su se formirali oko svih žrtava $\mathrm{TB}$, dok je društvo pokušavalo da razume prirodu bolesti i prihvati je na civilizovan način, budući da je zdravstveni problem sa brojnim socijalnim implikacijama. Savremene mere javnog zdravlja za borbu protiv širenja pandemije TB uspostavljaju se nakon otkrića Kohovog bacila u 19. veku, a pronalazak i masovna primena BCG vakcine u 20. veku uspostavljaju i prve okvire u globalnoj kontroli TB. Otkrićem streptomicina 1944. godine i isoniazida 1952. godine, započinje savremeno doba lečenja i kontrole TB, koje s pojavom rezistencije na lekove, koepidemije sa AIDS-om, zanemarivanja javnih zdravstvenih institutcija i aktuelne COVID-19 pandemije, uz ugrožena brojna zakonska prava zaraženih i obolelih osoba, uprkos stalnom društveno-ekonomskom napretku čovečanstva, postavlja nove izazove ka eliminaciji ove bolesti.

Brojni pokušaji društva, kroz vekove, da osmisli preventivne i terapijske mere za tuberkulozu, kroz različite nivoe socijalnih obaveza $i$ aktivnosti, imale su i imaju dubok uticaj na ljudski rod u celini, oblikujući dalju reakciju prema žrtvama ove smrtonosne bolesti.

Ključne reči: tuberkuloza, istorija, pravna moć, zakonska prava 